\title{
Assessing Grain Terminal Equipment Downtime Risk Using Simulation
}

\author{
Elena Veremeenko*, Tatyana Rogovenko
}

\author{
Don State Technical University, Rostov-on-Don, Russia \\ *Corresponding author. Email: lena_dedyaeva@mail.ru
}

\begin{abstract}
The risks arising from the grain terminal equipment downtime have been assessed for different types of incoming freight traffic flow and arrangement of the terminal queue. Simulation of the freight vehicle servicing process has been applied in combination with statistical modeling of the individual terminal station operating time. The dependencies of equipment downtime on the incoming flow intensity have been obtained.
\end{abstract} Keywords: risks, simulation, grain terminal, cargo transportation, equipment downtime

\section{INTRODUCTION}

In various fields of human activity, risk assessment has remained relevant for many years [1-4]. Risk as a versatility indicator of process characteristics may be used to make effective managerial decisions. In transport logistics, risk assessment holds a special place, since it requires the use of simulation and statistical modeling combined with optimization on one or several factors [5]. This paper is devoted to the risk assessment for a single element of such a complex transport and logistics process as servicing vehicles at a multifunctional seaport grain terminal.

For three consecutive seasons, the Russian Federation has been a leader in wheat exports and one of the top shippers of grain in general. The grain is mainly shipped for export through port terminals located in the Southern Federal District, which is the end of the North-South international transport corridor.

Motor vehicles play a significant role in transporting crops to the terminal territory [6]. In the Rostov Region, the bulk grain lorry flow is formed by both the grain carriage within the region collecting up to 12 million tons of grain per year and transportation of this cargo type from other regions of the European part of the RF (Figure 1) [7].

Since grain harvesting is seasonal, the issue of unevenly loaded transport network arises. In a limited time, a significant number of grain lorries arrive at the port to unload grain that creates an increased load on intercity roads and federal highways [8]. Figure 2 shows the possible routes for transporting grain to the Rostov port terminals, which create traffic jams of different intensity when merged onto the local traffic [9-12]. Along with the reduced motor road throughput, a number of negative factors associated with excessively loaded transport network can be distinguished [13]:

- the harmful impact of road transport on the region ecology;

- the emergence of spontaneous grain lorry parking on both intercity roads and federal highways;
- difficulties in road work (repair, cleaning and maintenance of roads);

- violation of traffic rules and the creation of accidental situations;

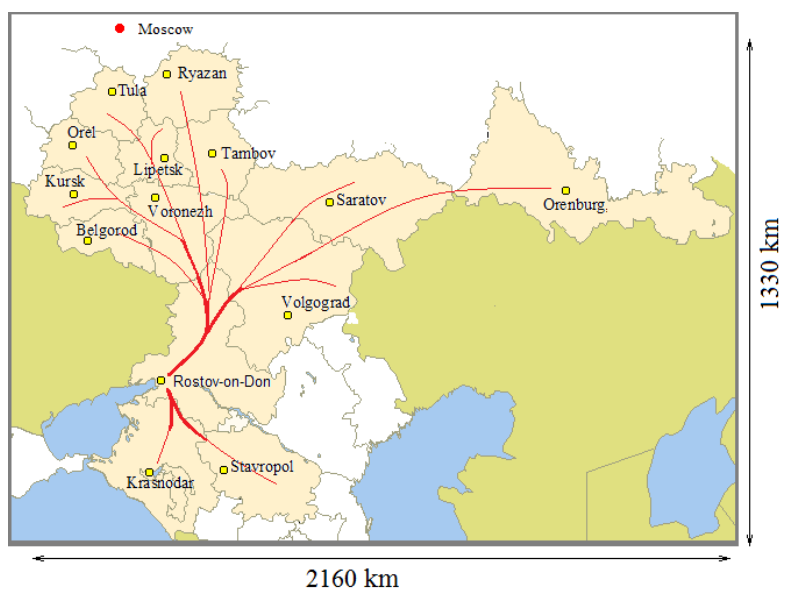

Figure 1 The russian regions forwarding crops by road through the Rostov region terminals

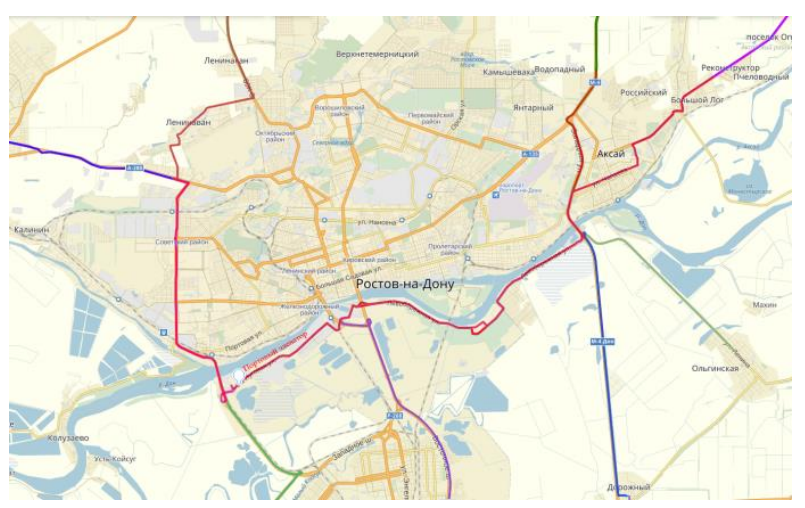

Figure 2 Merging the grain lorry routes onto the road network of Rostov-on-Don 
- the possibility of damage and theft of goods.

To solve the arising freight vehicle flow arrangement issues and reduce their downtime in a terminal queue, specialized traffic control systems, smart transport systems, electronic queues, and areas of preliminary waiting for unloading have been developed [14-18].

The uneven arrival of grain lorries creates another issue the grain terminal equipment downtime and the associated risks. An analysis of the grain terminal process allows revealing several reasons for equipment downtime: the absence of customers at a specific station in the terminal queue conditions and equipment failures for technical or organizational issues.

The sequence of service at a terminal capable of accepting several types of crops is most often arranged in one of two ways: a non-priority queue of FCFS type or a dynamic priority queue.

Each type of queue can be implemented for two types of incoming grain lorry flow: a simple random event stream (SR-stream) and preliminary on-line recording for service (POR-stream).

The incoming grain lorry flow depends on world demand for grain crops, the export policy of Russia, the marketing policy of a terminal, and other external factors.

\section{ASSESSING RISK}

To assess risks arising from the grain terminal equipment downtime depending on the incoming customer flow and the service queue type, simulation has been used in combination with statistical modeling of the service time at each terminal station.

In the research, the below definition of risk has been adopted: "risk is a consequence of an undesirable event" [1]. Undesirable event $A$ is the terminal equipment downtime, i.e. $A=\left\{T_{d_{k}}>0 \quad \forall k=1,2, \ldots, K\right\}$, where

$T_{d k}$ is the equipment downtime at the $k$ th terminal station.

Then, the risk can be determined by the formula:

$$
R=P(A) \cdot D
$$

where $D$ is the damage from downtime, $P(A)$ is the undesirable event probability. Damage $D$ is the product of the equipment downtime $T_{d}$ and the cost of one hour of operation. To assess probability $P(A)$, the distribution of lorries arriving at the terminal at a given flow intensity $\lambda(x)$, obtained as a result of simulation has been used.

The intensity of the SR-stream of lorries arriving at the terminal $\lambda(x)$ depending on the month of the year is determined by the formula:

$$
\lambda(x)=\frac{\delta \cdot y(x)}{0,144 \cdot d \cdot W}, 1 / \min
$$

where $W$ is the vehicle load capacity, $\mathrm{t} ; \delta$ is the terminal share in the total grain export, $\%$; $d$ is the number of days in an $x$ month; $y(x)$ is an approximating model of grain transshipment, and $x$ is the month of the year.
Statistical data available allows describing the grain transshipment volumes for both half-years by different nonlinear regression models.

$$
y(x)=\left\{\begin{array}{lll}
y_{I}(x) & \text { for } & x \in[1,6] \\
{ }^{I} I(x) & \text { for } & x \in[7,12]
\end{array} .\right.
$$

Based on the data on grain exports from Russia, regression models with a correlation coefficient of 0.98 have been chosen:

$$
\begin{gathered}
y_{I}(x)=1,30+0,92 \cdot x-0,099 \cdot x^{2} \text { for } x \in[1,6] ; \\
y_{I I}(x)=-109,31+35,81 \cdot x-3,64 \cdot x^{2}+0,12 \cdot x^{3} \text { for } \\
x \in[7,12] .
\end{gathered}
$$

The POR-stream intensity is a constant weighted average of the total grain exports for the year: $y(x)=y_{m}$. Then, the flow intensity is

$$
\lambda(x)=\lambda=\frac{\delta \cdot y_{m}}{0,144 \cdot d \cdot W}, 1 / \mathrm{min} .
$$

The time to pass each station $t_{k}$ is a random variable, since it depends on many external factors and the staff work peculiarities. Previous studies have shown that the threeparameter Weibull distribution is suitable to describe the station working hours [24]:

$$
F\left(t_{k}\right)=1-\exp \left(-\left(\frac{t_{k}-c_{k}}{a_{k}}\right)^{b_{k}}\right),
$$

where $c_{k}$ is the shift parameter equal to the minimum (rated) service time at the station; $a_{k}$ is the scale parameter; $b_{k}$ is the shape parameter, and $K$ is the number of terminal stations. Distribution parameters have been estimated by the maximum likelihood technique at a sample size of 50-120 observations.

For the incoming SR-stream, the time interval between lorries $\Delta t$ has an exponential distribution:

$$
F S R(\Delta t)=1-\exp (-\lambda(x) \cdot \Delta t),
$$

where $\lambda(\mathrm{x})$ is the flow intensity.

For the incoming POR-stream, the time interval between lorries $\mathrm{t}$ is determinate and equal to the maximum standard value of a single lorry service time at the terminal $\Delta t=\underset{1 \leq i \leq K}{\max }\left\{t_{\text {norm }_{i}}\right\}$.

The equipment downtime risks have been assessed on an example of a grain terminal with an export flow of about $3 \%$ of the total grain exports in Russia for the current season. The terminal has a series-parallel functional structure (Figure 3) [19-20]. Of the four unloading points, two are intended to receive wheat and one each sunflower seeds and barley [14, 21]. Of the total volume of grain crops received by the terminal during the year, $78 \%$ 
For a simple random stream, the risks depend on the grain

is wheat and $11 \%$ each is sunflower seeds and barley. The rated load capacity of a lorry is 30 tons.

The source simulation data has been the lorry arrival intensity $\lambda(x)$, the downtime damage $D$, the Weibull distribution parameters $a_{k}, \quad b_{k}, \quad c_{k}(k=1,2, \ldots, K)$, the cargo type, the incoming flow type, and the service queue type [22 -24]. For each set of source data, the simulation cycle has been repeated 50 times.

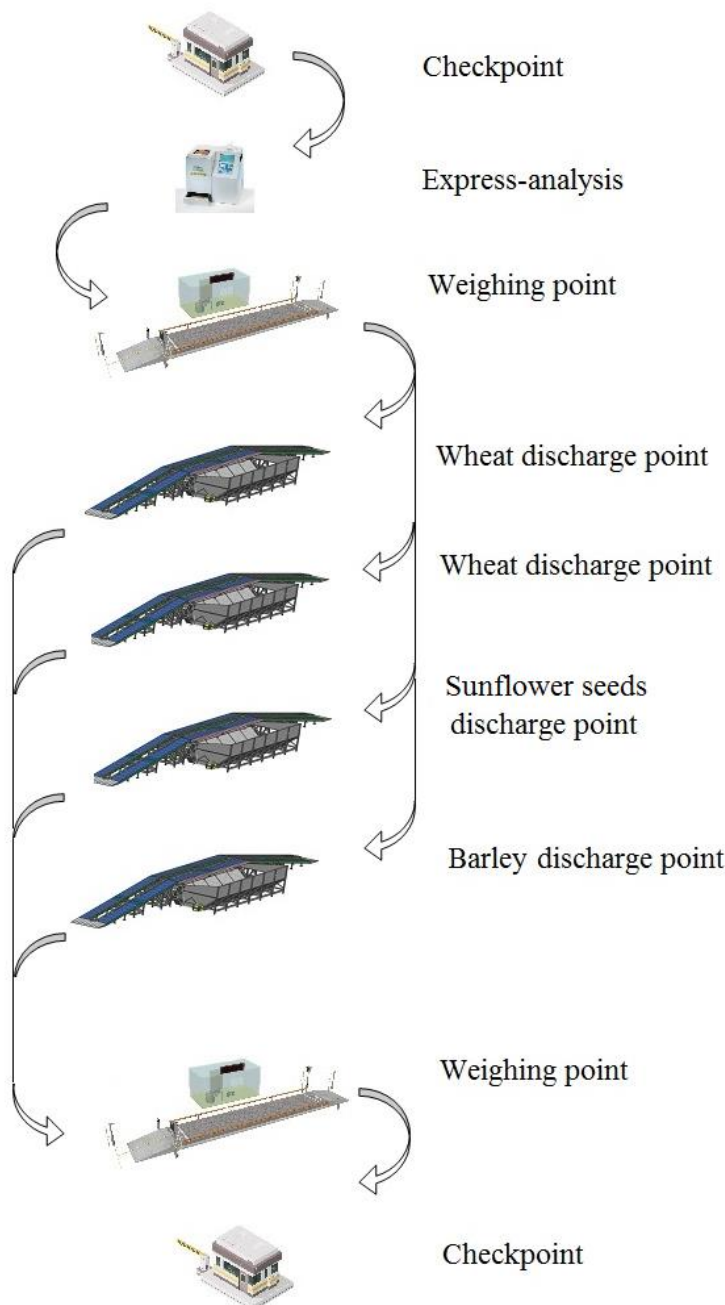

Figure 3 Layout to pass the terminal stations

The simulation results have shown that the use of dynamic priority queue is not effective to reduce the equipment downtime, since the arrival of grain lorries with sunflower seeds and barley is a rare event and the service time at tandem stations is too long to optimize the queue [25]. The incoming flow type is the dominant factor. Figure 4 shows the dependence of downtimes $T_{d}$ on the intensity $\lambda(x)$ : red and blue marks indicate the lorry and equipment downtime at the SR-stream mode, respectively, and purple and green ones reflect these values for the POR-stream mode.

The average equipment downtime risk values have fundamentally different dynamics by months of the year for different incoming flow arrangement ways (Figure 5). export model and tend to decrease in the second half of the year, when the lorry flow is most intense. For an online queue stream, the average risks vary in a limited area.

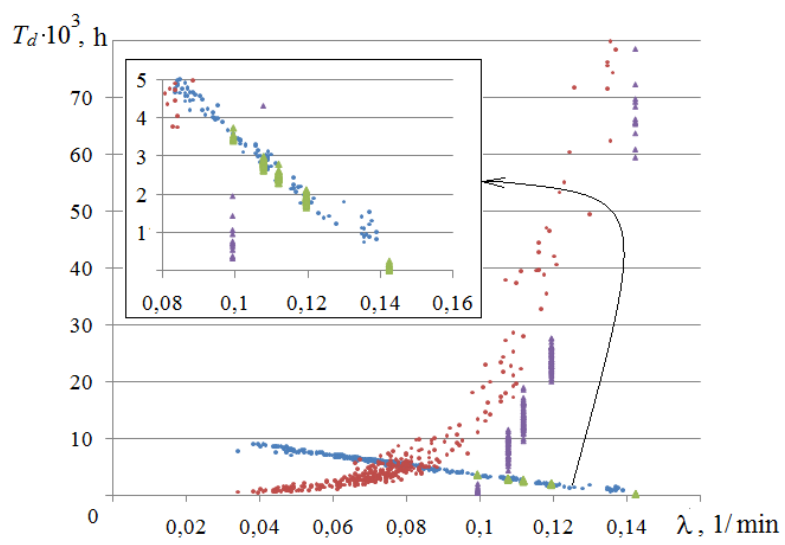

Figure 4 Total downtime depending on the lorry arrival intensity

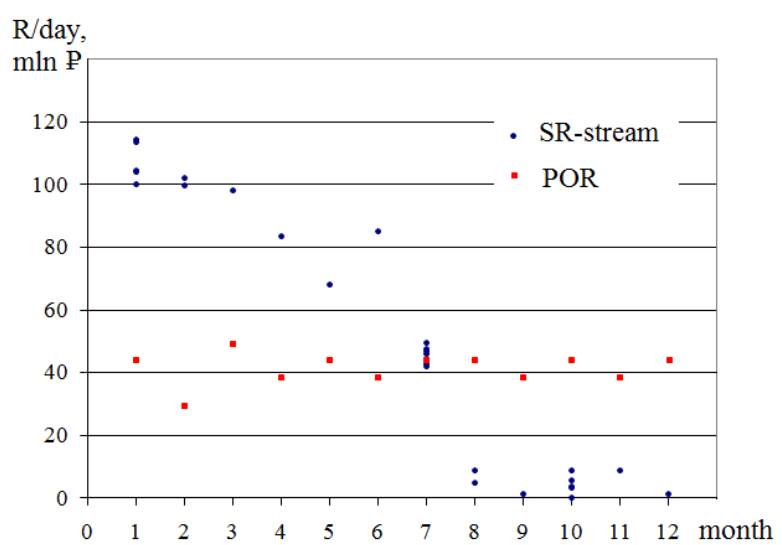

Figure 5 Change in average grain terminal equipment downtime risks during a year

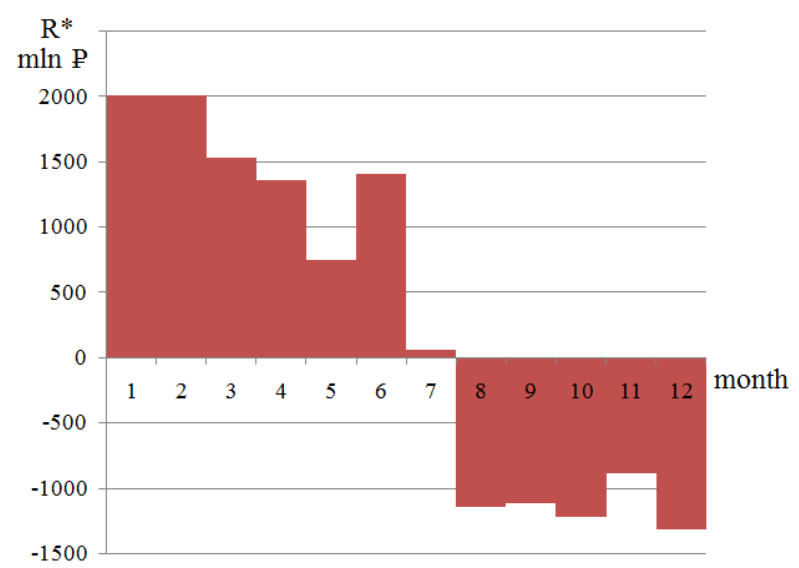

Figure 6 Difference between the grain terminal equipment downtime risks for the SR- and POR-streams 
Donu: analiz problem i puti ih resheniya. Vestnik evrazijskoj nauki, 2018. T. 10. № 1. P. 36.

[10] Zyryanov V., Simulation Network-Level Relationships of Traffic Flow. 2019 IOP Conference Series: Materials Science and Engineering

[11] Zyryanov V., Fialkin, V., Keridy, P., Integrated microsimulation to evaluate freight on urban network and operation at inner port area 2010 17th ITS World Congress

[12] Dombalyan A., Kocherga V., Semchugova E., Negrov N. Traffic forecasting model for a road section. Transportation Research Procedia 2017. pp. 159-165.

[13] Veremeenko A., Veremeenko E. Problemy vzaimodejstviya porta i avtomobil'nogo transporta. Inzhenernyj vestnik Dona. 2013. № 2 (25). pp. 117.

[2] D. MacLean, Values at risk, American Political Science Review, vol. 81, Issue 3, September, 1987, pp. 1057-1058. DOI: https://doi.org/10.2307/1962757

[3] Verstina, N., Badalova, A., Evseev, E. Assurance of heating systems maintenance reliability through the creation of a risk management system of the heatsupplying organizations (2019) E3S Web of Conferences, $\quad 97, \quad 01019 \quad$ DOI: 10.1051/e3sconf/20199701019

[4] Rogovenko, T., Zaitseva, M.. Statistical modeling for risk assessment at sudden failures of construction equipment. MATEC Web of Conferences. 129 (2017) 05014 . DOI: $10.1051 /$ matecconf/201712905014

[5] Ivanov, D. (2018). Structural Dynamics and Resilience in Supply Chain Risk Management. Springer, New York, ISBN 978-3-319-69304-0

[6] Pravdin N., Negpej V., Podkopaev V. Vzaimodejstvie razlichnyh vidov transporta: (primery i raschety). Transport, Moscow, 1989, ISBN 5-27700479-3

[7] Kostenko A., Eremina L. Logisticheskaya organizaciya perevozok predpriyatij sel'skohozyajstvennoj promyshlennosti. Logistika evrazijskij most, Krasnoyarsk, 2016. pp. 130-134.

[8] Fialkin, V., Veremeenko, E. Characteristics of Traffic Flow Management in Multimodal Transport Hub (by the Example of the Seaport) 2017 Transportation Research Procedia. pp. 205-211 DOI: 10.1016/j.trpro.2017.01.053

[9] Chernova A., Semchugova E., Solodovchenko I., Upravlenie gruzovym avtotransportom g. Rostova-na-
[14] Veremeenko E. Razrabotka adaptivnoj imitacionnoj modeli obsluzhivaniya avtomobil'nogo transporta na zernovom terminale. Mir transporta i tekhnologicheskih mashin. 2016. № 4 (55). pp. 90-96.

[15] Viskova A., Veremeenko E., Problemy i perspektivy rossijskogo rynka transportnologisticheskih uslug. Molodoj issledovatel' Dona. 2018. № 4 (13). pp. 36-39.

[16] Gorev A. Informacionnye tekhnologii v upravlenii logisticheskimi sistemami. Saint Petersburg, 2004. ISBN 5-9227-0018-9

[17] Semchugova, E., Chernova, A., Mironchuk, A. The model of formation of the elements of the information base for improving the route network 2018 Transportation Research Procedia. DOI: 10.1016/j.trpro.2018.12.103

[18] Dombalyan A., SHatalova E. Razvitie intellektual'nyh transportnyh sistem v mire Stroitel'stvo - 2015. 2015. pp. 81-82.

[19] Anily S., Bramel J. Approximations algorithms for the capacitated traveling salesman problem with pickups and deliveries // Naval Res. Logistics. 1999, pp. 654-670.

[20] Bent R., Van Hentenryck P. A two-stage hybrid algorithm for pickup and delivery vehicle routing problem with time windows // Computers \& Oper. Res. 2006. pp. 875-893.

[21] Esin K., Novikov A. Celochislennaya proizvodstvenno-transportnaya model' dlya perevozki 
Development», Rostov-on-Don 2018. DOI:

zerna. Mir transporta i tekhnologicheskih mashin. 2015. № 4 (51). pp. 111-118.

[22] Rogovenko, T., Zaitseva, M. Use of statistical simulation in construction planning MATEC Web of Conferences. $106 \quad$ (2017) 08011. DOI: $10.1051 /$ matecconf/201710608011

[23] Rogovenko, T., Zaitseva, M. Statistical modeling for assessment of dipper stick service life CATPID 2018; «International Conference on Construction and Architecture: Theory and Practice of Industry

\subsection{8/www.scientific.net/MSF.931.417}

[24] Horst Rinne, The Weibull Distribution: A Handbook, Chapman and Hall, 2008.

[25] Zyryanov V. Metody ocenki adekvatnosti rezul'tatov modelirovaniya. Inzhenernyj vestnik Dona. 2013. T. 25. № 2 (25). 132. 